\title{
EFFECTS OF DIARRHOEA ON WATER CONSUMPTION OF PIGLETS WEANED ON THE FIRST DAY AFTER BIRTH
}

\author{
Eva BARANYIOVÁ* and A. HOLUB \\ *Department of Biochemistry and Biophysics \\ University of Veterinary and Pharmaceutical Sciences, 61242 Brno
}

Received November 23, 1992

\begin{abstract}
Baranyiová Eva, A. Holub: Effects of Diarrhoea on Water Consumption of Piglets Weaned on the First Day after Birth. Acta vet. Brno, 62, 1993: 27-32.

Twenty-three Large White $x$ Landrace piglets weaned on the first day after birth and kept individually in cages in a thermoneutral environment were offered a liquid diet similar in its macronutrient content to sow's milk at $2 \mathrm{~h}$ intervals nine times a day. They were divided into two groups: clinically healthy piglets and diarrhoeic animals. After each feeding the diarrhoeic piglets were offered in addition camomile tea. Water consumption at individual feedings was measured 514 times in diarrhoeic piglets and 441 times in the controls from 3 to 10 days after birth.

The intake of the offered diet changed with age as was repeatedly described in our previous studies. The diarrhoeic piglets supplemented their water consumption by intake of camomile tea only in $83(16.1 \%)$ cases. Therefore their mean water consumption was lower than that of the controls: by $15.8 \%$ per animal and by $9.2 \%$ and by $9.4 \%$ per live body mass unit and per metabolic mass unit, respectively. The difference in actual water ingestion was significant on doys 5, 6,9 and 10 . Relative water consumption per live body mass of diarrhoeic piglets was significantly lower on day 5 and 6 , but higher on day 4 and 8 ; that per metabolic mass unit was lower on day 5,6 , and 10 , but higher on day 4 and 8 .

Diarrhoeic piglets lose more water than clinically healthy animals during the postnatal period. In our experiments they could make up for their water deficiency by increasing the intake of the diet and by additional consumption of camomile tea only relatively (expressed per live body mass and per metabolic mass) and for a limited length of time (only on 2 out of 8 days). Diarrhoeic piglets therefore increase their water turnover by oral ingestion, thus contributing relatively to the compensation of water loss in a partial way, but not attaining full compensation for the loss due to diarrhoea.
\end{abstract}

Sucking, liquid diet, camomile tea, postnatal development, functional ontogeny

Piglets kept with the sows show a higher water intake during the early postnatal period (Aumaitre 1964, 1965; Mount and Ingram 1971; Bauer et al. 1978; Bauer 1983). Their daily water intake from milk sucking or supplementary feeding or directly from drinking and su vementary feeding amounts to $23 \%$ of their live body mass or almost to $29 \%$ of their metabolic mass (Holub 1988, 1990).

The water intake of early-weaned piglets is even higher, amounting to $27 \%$ of their live body mass and to more than $40 \%$ of their metabolic mass (Holub and Ponížilová 1964; Holub 1988, 1990, 1991; Holub and Doležel in press).

Under these rearing practices piglets are often affected with secretory and malabsorption diarrhoea (Lecce 1986; Larsen and Schwartz 1987; S chmid and Walser 1991; Baranyiová and Holub in press), in consequence of which they utilize diet less efficiently and lose more water (Kelly et al. 1990). These adverse effects of diarrhoea are augmented by the fact that diarrhoeic piglets are unable to compensate for them by consuming a larger quantity of diet 
offered to them ad libitum. As a matter of fact, their consumption of the diet between the 3rd and 10th postnatal days is even reduced (Baranyiová and Holub in press). In which way diarrhoea affects their water ingestion during this period remains undisclosed.

\section{Materials and Methods}

Twenty-three Large White $x$ Landrace piglets from clinically healthy sows kept in a large-scale production unit were removed from the dams on the 1st day after birth and reared as described in our previous reports (Holub and Baranyiová 1989; Baranyiová and Holub 1991 and in press). Their nutrition was modified in that diarrhoeic piglets were offered camomile tea flavoured with Glukopur in addition to the diet fed ad libitum at 2-h intervals.

The intake of the diet was measured in $\mathbf{5 1 4}$ feedings in diarrhoeic piglets and in 441 feedings in clinically healthy controls.

Statistical analysis of the results of the measurements on individual days was performed with Student's t-test and their variability was expressed in terms of standard errors of the means.

\section{Results}

The actual water intake at individual feedings during the observation period increased with advancing age in both diarrhoeic and clinically healthy piglets; in the former it did so more than 1.5 times, in the latter it doubled. On the whole, however, diseased piglets consumed approximately $15 \%$ less water than healthy animals between 3 and 10 days after birth. However, this ratio varied from day to day and the difference proved significant $(P<0.01)$ only on days $5,6,9$ and 10 (Table 1).

Expressed per live body mass unit, the water consumption of diarrhoeic piglets during the same period was $9.2 \%$ lower than in healthy animals. The daily difference was even more conspicuous when the results were expressed per animal: it was lower only on days 5 and $6(P<0.01)$, but higher on days 4 and $8(P<0.05)$ (Table 2).

A similar pattern became apparent when the water consumption was related to metabolic mass $\left(\mathrm{kg}^{0.75}\right)$. In diarrhoeic piglets it was $9.4 \%$ lower on days 5 , 6 and $10(P<0.01)$, but higher on days 4 and $8(P<0.05)$ (Table 3$)$.

The diet, however, was not the exclusive source of water for diarrhoeic piglets. The 514 feedings offered to these animals were in $83(16.1 \%)$ cases supplemented by intake of camomile tea. Since great difference existed in the intake of this supplementation on individual days, its contribution to total ingested water varied from day to day, though it was not negligible. It was largest, accounting for more than one third (37\%) on day 6 , constituted more than a quarter $(26.8 \%)$ on day 5 and almost a fifth $(17.3 \%)$ on day 4 . On the remaining days except day 10 on which no camomile tea was consumed at all the proportion of this additional ingested water was about 5 to $6 \%$ (Table 1 ).

\section{Discussion}

Water consumption by piglets during the early postnatal period is relatively very high (Holub and Ponížilová 1964; A umaitre 1964, 1965; Bauer et al. 1978; Bauer 1983), equalling that of 250 times smaller infant rats (Křeček et al. 1856; Křeček and Křrečková 1957, 1961; Křeček 1962). This was also the case with our clinically healthy piglets and the age-dependent changes observed corresponded to the data obtained in similarly early-weaned piglets 
(Holub 1990, 1991; Baranyiová and Holub in press; Holub and Doležel in press).

Similarly to the ingested quantities of diet, energy and macronutrients (Baranyiova and Holub in press) the intake of water was lower in diarrhoeic piglets than in the controls. Actually, expressed per animal, it was so on 4 out of the 8 days. Relatively, the results were less unequivocal: expressed per live body mass, the water intake was lower on 2 days, but higher on the remaining days; expressed per metabolic mass, it was lower on 3 days, but higher on 2 days.

Like other mammalian polycotous neonates, suckling piglets cover their hydration and nutritional requirements in inseparable union, the ratio of water to the other milk components being determined by the dam. Therefore also the coverage of hydration requirements of piglets is prandial in character, an observation

Table 1

Water consumption per feeding by diarrhoeic and control early-weaned piglets aged 3 to 10 days

\begin{tabular}{|c|c|c|c|c|c|}
\hline d & $\mathbf{n}$ & $\begin{array}{c}\text { Diarrhoeic piglets } \\
\text { Water consumption } \\
(\mathbf{g})\end{array}$ & $\mathbf{n}$ & $\begin{array}{l}\text { Healthy piglets } \\
\text { Water consumption } \\
\text { (g) }\end{array}$ & $\begin{array}{l}\text { Significance of } \\
\text { the differences }\end{array}$ \\
\hline $\begin{array}{r}3 \\
4 \\
5 \\
6 \\
7 \\
8 \\
9 \\
10\end{array}$ & $\begin{array}{r}60 \\
113 \\
99 \\
90 \\
72 \\
35 \\
27 \\
18\end{array}$ & $\begin{array}{l}17.7 \pm 2.0 \\
23.2 \pm 1.4 \\
19.4 \pm 1.1 \\
18.6 \pm 1.8 \\
18.4 \pm 1.4 \\
25.6 \pm 2.0 \\
30.4 \pm 3.1 \\
27.8 \pm 2.3\end{array}$ & $\begin{array}{l}18 \\
67 \\
18 \\
32 \\
36 \\
90 \\
90 \\
90\end{array}$ & $\begin{array}{l}20.6 \pm 1.8 \\
21.1 \pm 0.8 \\
25.6 \pm 1.5 \\
26.0 \pm 1.4 \\
18.1 \pm 1.1 \\
22.6 \pm 0.6 \\
40.0 \pm 1.2 \\
41.1 \pm 1.2\end{array}$ & $\begin{array}{l}\text { n. s. } \\
\text { n. s. } \\
\mathbf{P}<0.01 \\
\mathbf{P}<0.01 \\
\text { n. s. } \\
\text { n. s. } \\
\mathbf{P}<0.01 \\
\mathbf{P}<0.01\end{array}$ \\
\hline
\end{tabular}

Table 2

Relative water consumption per feeding by diarrhoeic and control early-weaned piglets aged 3 to 10 days

\begin{tabular}{|c|c|c|c|c|c|c|}
\hline $\begin{array}{l}\text { Live body } \\
\text { mass }(\mathrm{kg})\end{array}$ & $d$ & $\mathbf{n}$ & $\begin{array}{l}\text { Diarrhoeic piglets } \\
\text { Water consumption } \\
\qquad\left(\mathrm{g} \cdot \mathbf{k g}^{-1}\right)\end{array}$ & $\mathbf{n}$ & $\begin{array}{c}\text { Healthy piglets } \\
\text { Water consumption } \\
\left(\mathbf{g} \cdot \mathbf{k g}^{-\mathbf{1}}\right)\end{array}$ & $\begin{array}{l}\text { Significance } \\
\text { of the } \\
\text { differences }\end{array}$ \\
\hline $\begin{array}{l}1.32 \\
1.35 \\
1.39 \\
1.46 \\
1.52 \\
1.50 \\
1.43 \\
1.58\end{array}$ & $\begin{array}{r}3 \\
4 \\
5 \\
6 \\
7 \\
8 \\
9 \\
10\end{array}$ & $\begin{array}{r}60 \\
113 \\
99 \\
90 \\
72 \\
35 \\
27 \\
18\end{array}$ & $\begin{array}{l}13.4 \pm 1.5 \\
17.2 \pm 1.1 \\
33.9 \pm 0.8 \\
12.7 \pm 1.2 \\
12.1 \pm 0.9 \\
17.0 \pm 1.3 \\
21.2 \pm 2.1 \\
17.7 \pm 1.5\end{array}$ & $\begin{array}{l}18 \\
67 \\
18 \\
32 \\
36 \\
90 \\
90 \\
90\end{array}$ & $\begin{array}{l}16.7 \pm 1.5 \\
14.3 \pm 0.5 \\
19.1 \pm 1.1 \\
17.5 \pm 0.4 \\
10.3 \pm 0.7 \\
13.3 \pm 0.4 \\
22.4 \pm 0.7 \\
21.8 \pm 0.7\end{array}$ & $\begin{aligned} & \text { n. s. } \\
& \mathbf{P}<0.05 \\
& \mathbf{P}<0.01 \\
& \mathbf{P}<0.01 \\
& \text { n. s. } \\
& \mathbf{P}<0.05 \\
& \text { n. s. } \\
& \text { n. s. }\end{aligned}$ \\
\hline
\end{tabular}

Table 3

Relative water consumption per feeding (related to metabolic mass, $\mathbf{k g}^{0.75}$ ) by diarrhoeic and control early-weaned piglets aged 3 to 10 days

\begin{tabular}{|c|c|c|c|c|c|c|}
\hline $\mathrm{d}$ & $\begin{array}{c}\text { Body mass } \\
\left(\mathbf{k g}^{0.75}\right)\end{array}$ & $\mathbf{n}$ & $\begin{array}{l}\text { Diarrhoeic piglets } \\
\text { Water consumption } \\
\text { (g) }\end{array}$ & $\mathbf{n}$ & $\begin{array}{c}\text { Healthy piglets } \\
\text { Water consumption } \\
(\mathrm{g})\end{array}$ & $\begin{array}{c}\text { Significance } \\
\text { of the } \\
\text { differences }\end{array}$ \\
\hline $\begin{array}{r}3 \\
4 \\
5 \\
6 \\
7 \\
8 \\
9 \\
9 \\
10\end{array}$ & $\begin{array}{l}1.30 \\
1.25 \\
1.28 \\
1.33 \\
1.37 \\
1.36 \\
1.31 \\
1.41\end{array}$ & $\begin{array}{r}60 \\
113 \\
99 \\
90 \\
72 \\
35 \\
27 \\
18\end{array}$ & $\begin{array}{l}14.4 \pm 1.7 \\
18.5 \pm 1.1 \\
15.1 \pm 0.8 \\
14.0 \pm 1.4 \\
13.5 \pm 1.0 \\
18.8 \pm 1.5 \\
23.2 \pm 2.3 \\
19.8 \pm 1.7\end{array}$ & $\begin{array}{l}18 \\
67 \\
18 \\
32 \\
36 \\
90 \\
90 \\
90\end{array}$ & $\begin{array}{l}17.3 \pm 1.6 \\
15.7 \pm 0.6 \\
20.5 \pm 1.2 \\
19.3 \pm 1.0 \\
11.9 \pm 0.8 \\
15.2 \pm 0.4 \\
25.9 \pm 0.8 \\
25.6 \pm 0.8\end{array}$ & $\begin{array}{c}\text { n. s. } \\
\text { P }<0.05 \\
P<0.01 \\
P<0.01 \\
\text { n. s. } \\
\text { P }<0.05 \\
\text { n. s. } \\
\text { P }<0.01\end{array}$ \\
\hline
\end{tabular}


pointed out in a previous report (Holub 1990), and this applies apparently also to diarrhoeic piglets. Consideration was given to this fact by adjusting the proportion of water in the liquid diet to $176 \mathrm{~g}$ per $1 \mathrm{MJ}$ energy and to $15.3 \mathrm{~g}$ per $1 \mathrm{~g}$ protein. By ingestion of water from camomile tea the proportion of water intake was naturally increased: on day 6 by as much as $60 \%$, to 283 per $1 \mathrm{JM}$ of energy and to $24.5 \mathrm{~g}$ per $1 \mathrm{~g}$ protein.

Therefore expressions such as hunger, thirst or satiety have a different meaning in neonates than in grown-up subjects (Adolph 1968; Holub 1968, 1990, 1991; Phifer and Hall 1988). Neonates not only show considerable hydration and a high turnover of water, but also lose more water when diarrhoeic (Argenzio et al. 1984; Simmons and Bywater 1991; McLee et al. 1992). Moreover, the absorption activity of their small intestine undergoes an abrupt development (Henriquez de Jesus 1974ab; Burton et al. 1980; Smith 1988) and is affected in addition by diarrhoea-associated lesions. The colon shows a different activity that can compensate for water loss by increased resorption. This function, however, does not come into operation until piglets are older (Argenzio et al. 1984). Not even antisecretory factor which inhibits water loss in enterotoxic diarrhoea is produced perinatally or in the early postnatal period (McEwan et al. 1990ab).

The afore-mentioned facts offer a possible explanation of the problems of oral rehydration which is otherwise regarded as a highly useful therapeutic procedure in the management of neonatal diarrhoea (Bywater and Woode 1980; Simmons and Bywater 1991). However, this procedure should be repeated daily (Anderson and Backstrom 1984), otherwise it fails. The finding that the intake of additional water offered to diarrhoeic piglets in camomile tea compensated for their water loss only relatively (expressed per live body mass unit and per metabolic mass unit) and for a limited length of time (for a quarter of the observation period) shows that during the first 10 postnatal days the capacity of piglets to make up for their water deficiency by increased fluid intake is limited. Similar observations have been reported also for older piglets (McLeese et al. 1992). Therefore rehydration routes other than oral fluid therapy should not be left out of consideration.

\section{Vliv průjmů na konzum vody u selat odstavených $\mathbf{v}$ prvním dnu po narození}

Selata (23 kusů) plemene bílého ušlechtilého $\mathrm{x}$ landrace odstavená $\mathrm{v}$ prvním dnu po narození, individuálně odchovávaná $\mathrm{v}$ termoneutrální zóně na tekuté dietě obsahem makronutrientů podobné mléku prasnic (byla jim nabízena devětkrát denně ve dvouhodinových intervalech), jsme rozdělili na jedince klinicky zdravé a postižené průjmy. Po nabídce diety jsme selatům průjmujícím umožňovali navíc sát ad libitum slabý čajový odvar. Od třetího do desátého dne po narození jsme u obou skupin určovali konzum vody, u selat diarhoických 514krát, u kontrolních 441 krát.

Velikost saných porcí diety se $\mathrm{u}$ obou skupin selat $\mathrm{s}$ věkem měnila způsobem, který jsme již dříve opakovaně popsali. Čajovým odvarem si je nemocná selata doplňovala nepř́liš často, pouze třiaosmdesátkrát, tedy při $16,1 \%$ nabídek. Proto konzumovala méně vody; průměrně na kus o $15,8 \%$ na hmotnost živou - 9,2 a na metabolickou o 9,4\%. Průkazně tomu tak bylo absolutně dne pátého, šestého, devátého a desátého relativně, na živou hmotnost dne pátého, šestého 
a na metabolickou i desátého, dne čtvrtého a osmého tomu bylo naopak; ingesce vody byla relativně větší.

Diarhoická selata ztrácejí v postnatálním údobí vody víc než kontrolní. Jsou však $s$ to řešit svůj vodní deficit zvětšením sané porce tekuté diety a jejím doplňováním čajem jen relativně (na živou a metabolickou hmotnost) a časově omezeně (pouze ve dvou $z$ osmi sledovaných dnů). Orální ingescí tedy svủj vodní obrat zvyšují, ke krytí vodních ztrát dílčím způsobem, relativně, přispívají, ale plně jej nekompenzují.

\section{Влияние поноса на потребление воды поросят, отпученных} на первые сүтки после рождения

Поросята (23 голов) белого породистого племени $\mathrm{x}$ ландрейс, отлученные от матки на первые сүтки после рождения, индивидуально содержимые в термонейтральной зоне на жидкой диете с содержанием макронутриентов, похожей на молоко свиноматок (кормление девять раз в сутки с двухчасовыми интервалами), разделили на клинически. здоровые особи и особи, страдающие поносами. Предлагая поросятам, страдающим поносами, диету, мы, вдобавок, предоставляли им возможность потреблять по желанию слабый чай. С третьих по десятые сутки после рождения у обеих групп определяли потребление воды - у поросят с поносами 514 раз, у контрольных поросят 441 раз.

Величина потребляемых доз диеты у обеих групп поросят с возрастом менялась ранее нами повторно описанным способом. Потреблением чая больные поросята дополняли пищу не слишком часто, только восемьдесят три раза, следовательно в 16,1 \% предлагаемых случаев. Поэтому они потребляли меньше воды, в среднем на голову на $15,8 \%$ к живой массе на 9,2 и метаболической - на 9,4\%. Абсолютно это четко наблюдалось на пятые сүтки, шестые, девятые и десятые относительно, к живой массе - пятые, шестые сүтки и к метаболической - десятые сүтки, на четвертые и восьмые сүтки наоборот; потребление воды было относительно больше.

Поросята с поносом в послеродовой период теряют по сравнению. с контрольной группой больше воды. Они однако в состоянии свою нехватку воды решить увеличением всасываемой дозы жидкой диеты и ее пополнением чаем лишь относительно (к живой и метаболической массе). Следовательно, они үвеличивают оборот воды оральным. потреблением пишь частично, способствуя покрытию ее потерь, но. они не в состоянии данные потери полностью компенсировать.

\section{References}

ADOLPH, E. F.: Origins of physiological regulations. New York-London, 1968, 147 p.

ANDRESON, K. L.-BACKSTROM, L.:- Fluid intake response of recently weaned pigs to administration of an oral glucose-glycine electrolyte formulation. Zbl. Vet. Med. A, 31, 1984: 296-302

ARGENZIO, R. A.-MOON, H. W.-KEMENY, L. J.-WHIPP, S. C.: Colonic compensation in transmissible gastroenteritis of swine. Gastroenterology, 86, 1984: $1501-1509$

AUMAITRE, A.: Le besoin en eau du porcelet: Étude de la consommation d'eau avant le sevra- ge. Ann. Zootech., 13, 1964: 183-198 
AUMAITRE, A.: Der Wasserbedarf des Ferkels. Z. Tierphysiol. Tierernähr. Futtermittelkde, 20, 1965: 209-217

BARANYIOVÁ, E.-HOLUB, A.: The effect of diarrhoea on food intake of piglets weaned on the day of $\iota$ irth. In press.

BARANYIOVÁ, E.-HOLUB, A.: Scouring piglets and their feeding behaviour. In: Proceedings of the pth International Congress on Animal Hygiene. Vol. III. Leipzig 1991, p. 1090 to 1094

BAUER, W.: Einflussfaktoren auf den Tränkwasserverbrauch und die Tränkwasseraufnahme durch Saugferkel und abgesetzte Ferkel. Arch. exp. Veter.-Med., 28, 1983: 333-340

BAUER, W.-OBER, G. - SCHLEMKER, G.: Zum Tränkwasserverbrauch wachsender Schweine. Mh. Vet. Med., 23, 1978: $497-500$

BURTON, K. A.-JAMES, P. S.-SMITH, M. W.-YOUNG, J. D.: Different pathways

for lysine transport across neonatal pig intestine. J. Physiol., 308, 1980: 451-464

BYWATER, R. J. - WOODE, G. N.: Oral fluid replacement by a glucose glycine electrolyte formulation in $\mathrm{E}$. coli and rotavirus diarrhoea in pigs. Vet. Rec., 106, 1980: 75-78

HOLUB, A.: Funkční periodizace časného postnatálního vývoje u selat. VSZZ Brno, 1968, 125 p.

HOLUB, A.: Postnatale Änderungen im Nahrungsaufnahmeverhalten von Ferkeln. Mh. Vet. Med., 43, 1988: $857-860$

HOLUB, A.: Effect of rearing practices on the water consumption by piglets in the first eight weeks after birth. Acta vet. Brno, 59, 1990: 129-137

HOLUB, A.: Konzum vody selaty časně odstavovanými v různém věku na tekutou dietu. Vet. Med. (Praha), 36, 1991: 415-422

HOLUB, A.-BARANYIOVÁ, E.: Radiačně ošetřená mléčná krmná směs ve výživě časně odstavených selat. Vet. Med. (Praha), 34, 1989: 545-552

HOLUB, A.-DOLEŽEL, F.: Vliv denní frekvence sání na spotřebu tekuté diety u raně odstavených selat. In press.

HENRIQUEZ DE JESUS, C.-SMITH, M. W.: Sodium transport by the small intestine of new-born and suckling pigs. J. Physiol., 243, 1974a: 211-224

HENRIQUEZ DE JESUS, C.-SMITH, M. W.: Protein and glucose induced changes in sodium transport across the pig small intestine. J. Physiol., 243, 1974b: 225-242

KELLY, D. - O'BRIEN, J. J.-MCCRACKEN, K. J.: Effect of creep feeding on the incidence, duration and severity of post-weaning diarrhoea in pigs. Res. Vet. Sci., 49, 1990: 223-228

KRECCEK, J.: Údobí odstavu a vodni metabolismus. Praha, 1962, 133 p.

KŘEČEK, J.-KŘECKKOVÁ, J.: The development of the regulation of water metabolism. III. The relation between water and milk intake in infant rats. Physiol. bohemoslov., 6, 1957: $26-34$

KŘECEK, J.-KŘEKKOVA, J.-DLOUHA, H.: On problems on the regulation of water intake in newborn mammals. Physiol. bohemoslov., 5, 1956: 33-37

LARSEN, L. A. - SCHWARTZ, K. J.: Differential diagnosis of baby pig diarrhea. Iowa State Univ. Vet., 49, 1984: 84-90

LECCE, J. G.: Diarrhea: The nemesis of the artificially reared, early weaned piglet and strategy of defense. J. Anim. Sci., 63, 1986: $1307-1313$

McEWAN, G. T. A.-SCHOUSBOE, B.-SKADHAUGE, E.: Effect of antisecretory factor on Escherichia coli STe enterotoxin-induced alkalinisation of pig jejunal acid microclimate. Pflügers Arch., 417, 1990a: 174-179

McEWAN, G. T. A.-SCHOUSBOE, B.-NIELSEN, C. G.-SKADHAUGE, E.: Effect of age on the secretory capacity of pig small intestine in vivo and in vitro. Amer. J. Physiol., 259, 1990b: G474-G480

MCLEESE, J. M.-TREMBLAY, M. L.-PATIENCE, J. F.-CHRISTISON, G. I.: Water intake patterns in the weanling pig: effect of water quality, antibiotics and probiotics. Anim. Prod., 54, 1992: 135-142

MOUNT, L. E.-INGRAM, D. L.: The pig as a laboratory animal. London-New York, 1971, $175 \mathrm{p}$.

PHIFER, C. B.-HALL, W. G.: Ingestive behavior in preweanling rats: emergence of postgastric control. Amer. J. Physiol., 255, 1988: R199-R199

PONÍŽILOVÁ, E.-HOLUB, A.: Vývoj selat odstavených druhého dne života. XI. Bilance dusíku u selat chovaných na semisyntetické vysokokalorické dietě $\mathrm{v}$ prvých čtyřech týdnech života. Čs. fysiol., 13, 1964: 258-259

SCHMID, G. - WALSER, K.: Erkrankungen der Ferkel. In „Neugeborenen und Säuglingskunde der Tiere“. Enke Verlag, Stuttgart, 1991, pp. 414-462

:SIMMONS, R. D. - BYWATER, R. J.: Oral rehydration in the management of neonatal diarrhea in livestock. Compend. Cont. Educ. Pract. Vet., 13, 1991: 345-348

SMITH, M. W.: Postnatal development of transport function in the pig intestine. Comp. Biochem. Physiol. A 90, 1988: 577-582 